\title{
Reshoring: implementation issues and research opportunities
}

Barbara Ocicka, Ph.D.

University of Lodz Department of Logistics, Faculty of Management

\section{Introduction}

In the $21^{\text {st }}$ century, there are many macro and micro factors impacting international and global supply chains configurations. On the one hand, the external business environment is increasingly demanding because of longterm megatrends impacting civilization development as well as due to short-term shocks and risks that occur suddenly. To mention a few,-that managers should consider: economic downturn, immigration wave, political instability in some regions or other serious threats for sustainable development. On the other hand, companies face new challenges on microscale, among others: great pressure on costs reduction, demanding customers on highly competitive markets, continuous searching for excellence and innovation.

Offshoring from the high-cost countries to low-cost emerging markets was a dominant strategy of supply chain management in the late 1990s and 2000s. Several motives can explain this trend, among others: cost advantage, diversification of suppliers or access to local markets (Monczka et al. 2010, p. 210; Blecker, Gemuenden 2006, p. 254; Young et al. 2009, p. 321). Currently, reshoring offers 
the new perspective for supply chains configuration and processes integration between business partners. A reshoring phenomenon has been noticed-where companies have moved back their business activities to their countries or regions of origin. Additionally, it is worth underlining that some of just mentioned micro and macro factors may change the trend in favour of reshoring.

This global shift has been receiving significant attention in the professional articles and has been the subject of numerous scientific studies and consulting reports. Some research studies were also made in particular countries, especially in the U.S, UK or Germany. Reshoring requires from both researchers and managers a holistic supply chain perspective and deep knowledge of how supply chain configuration impacts its economic, social and environmental performance.

The main purpose of the article is to set out the potential impact of reshoring on value delivered in international and global supply chains and to outline research opportunities in this field. Results of the literature review and the questionnaire-survey on the Total Cost of Acquisition analysis are guidelines for the author's considerations.

The paper proceeds as follows: First, the concept of value creation in contemporary supply chains is discussed. Second, the reshoring strategy is defined and its phenomenon is described in light of empirical studies in different countries. Third, the plethora of reshoring drivers is developed and potential effects are presented. Next, the reshoring significance in supply chains management and its limitations are discussed. Finally, future potential research opportunities are outlined.

\section{Value creation in supply chain management}

In the light of the Global Supply Chain Forum reference model, supply chain management is the integration of key business processes from end user through original suppliers that provides products, services and information that add value for customers and other stakeholders (Lambert, 2001, p. 100). There are three elements of the SCM framework: supply chain network structure, supply chain business processes and supply chain management components, which create supply chain configuration. Supply chain designing is a dynamic capability, which is the ability to continuously integrate, develop and reconfigure competencies of business partners (Arlbjørn, Mikkelsen 2014, p. 61).

The purpose of business partners in supply chains is to create and deliver value for different groups of stakeholders, such as: companies' owners, supervisory 
boards and management, employees, clients, consumer organisations, state and its agenda, local communities or ecologists. The perspective of goals and expectations of the interest groups determines three dimensions of the value creation in supply chains: economic, social and environmental. This conception refers to J. Elkington, who proposed The Triple Bottom Line framework and recommended a simultaneous management and balancing of the following aspects: economic, ecological and social (Elkington 1998, p. 12). This approach to value management is reflected in the sustainable supply chain management defined as the strategic, transparent integration and achievement of an organisation's social, environmental and economic goals in the systematic coordination of key inter organisational business processes for improving the long-term economic performance of the individual company and its supply chains (Carter, Rogers 2008, p. 15).

In the current global economy, companies stronger than ever face the challenge to manage and optimize their operations taking into account economic, social and environmental performance. The achievement of the value based on just mentioned three criteria is the essence of the phenomenon of best practices in business (Rutkowski, 2009, pp. 23-48). The necessity of benefits achievement in economic, social and environmental categories as well as the scope of best practices in logistics and supply chain management may be found in research projects carried out on the international arena like: Trends of global supply chain leaders realised by the University of Denver, MIT Supply Chain 2020, UK Government Freight Best Practice Programme, US Smart Way Programme launched by the Environmental Protection Agency.

\section{Reshoring phenomenon}

Reshoring is a part of the dynamics of companies' internationalization strategies focused on transferring business operations back to their countries or regions of origin. This strategy has many labels referred to reversed course of offshoring, such as: back-shoring, insourcing, back-sourcing, back-reshoring, near-reshoring. It is in line with Gray et al., who explained why the reshoring phenomenon should not be examined in isolation but rather as a reversion of a prior offshoring decision (Gray et al. 2013, pp. 27-31). As a result, reshoring is characterized by the following peculiarities: firstly, it is a revision of a previous offshoring choice and secondly, production is relocated to the company's home country or home region (Ancarani et al. 2015, pp. 141-143; Fratocchi et al. 2014, pp. 55-56). 


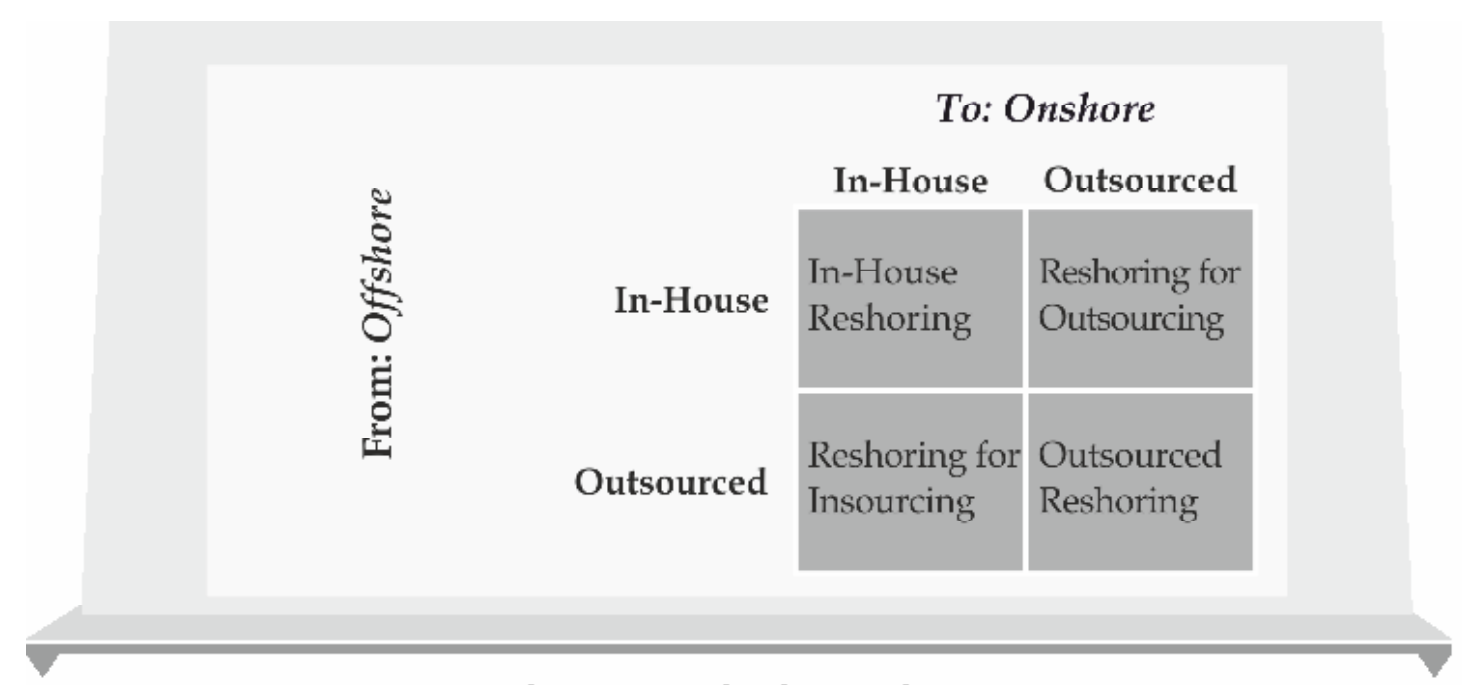

Figure 1. Reshoring options

Source: Gray et al. 2013 , p. 27

The term is referred to both manufacturing being brought home occurred in a wholly owned facility in an offshore location as well as in the factory of an offshore supplier. The fundamental questions are: where do companies develop manufacturing and sourcing and how are they changing the locations and restructuring supply chains? Regarding two location dimensions as the axes: onshore and offshore, four working definitions or iterations of the reshoring strategy were proposed (figure 1).

- in-house reshoring refers to the location of manufacturing activities, which are being performed in facilities owned abroad, back to facilities in the home country,

- reshoring for outsourcing refers to relocating in-house manufacturing activities from abroad, back to suppliers in the home country,

- reshoring for insourcing describes the change when company relocates manufacturing activities being outsourced to offshore suppliers back to its facilities in the home country,

- outsourced reshoring refers to the process of relocating manufacturing activities from offshore suppliers back to onshore suppliers.

Reshoring is happening in different industries. Based on the U.S. market, the highest number of cases come from electrical equipment, appliance and component manufacturing, transportation equipment manufacturing and 
computer and electronic product manufacturing (Van den Bossche et al. 2014, p. 27). Moreover, it is important to underline that reshoring applies to more industries than manufacturing and could also be defined as the practice of bringing outsourced services back to the location from which they were originally offshored (Cushman and Wakefield, 2015, p. 3). The information technology sector is an example, in which such challenges as time zone differences, identity theft, privacy concerns and issues with utility infrastructure abroad led some companies to return their IT operations to the U.S. (International Economic Development Council, 2015).

In the U.S. context, reshoring is the practice of bringing manufacturing and services back to the U.S. from overseas. There are certain examples of reshoring companies such as Chrysler, General Electric, Mitchell Metal Products, Motorola Solutions, Universal Plastics (Reshoring Initiative, 2016). This strategy can simultaneously be observed in the United Kingdom. According to 2014 study of almost 300 companies conducted by EEF, the manufacturers' organization, one in six British companies has reshored production in the past 3 years, others consider this decision (Cranfield University 2015, p. 3). Time-series analysis of data regarding dynamics of German reshoring activities over the past 15 years shows that every fourth to sixth offshoring activity is countered by a reshoring activity within 2 to 5 years (Kinkel 2014, p. 64).

Most publications and studies refer to reshoring development from perspective of companies originating from highly developed countries, especially the U.S. and located in Western Europe. There is lack of research studies and analysis of the reshoring role in supply chains of companies from Central and Eastern Europe, that develop their operations globally.

\section{Drivers of reshoring}

In the past, different research studies identified offshoring drivers as the dominant strategy in international and global supply chains management. The following determinants were identified as the most important:

- cost savings due to lower prices of production factors, diversification of sourcing markets, reduced dependence on local supplies (Blecker, Gemuenden 2006, p. 254),

- cost advantage improvement, cost reduction, global pressure, geographical expansion, entering new local and regional markets (Kamauff, Spekman 2008, p. 16),

- cost decrease in comparison to local suppliers, access to new markets and 
searching for unique technologies, locally unavailable capabilities or resources (Young et al. 2009, p. 321),

- lower purchase price/cost, greater access to product technology and improved supplier relationships (Monczka et al. 2010, p. 210).

What are main reasons for supply chain restructuring in sourcing and manufacturing? According to L.M. Ellram et al., there is a number of factors that are drivers of the strategic change:

- the volatile cost of fuel and associated transportation costs,

- the rising cost of labour in low-cost countries,

- the slowing of the global supply chain due to the shipping industry adoption of slow steaming,

- the improving ratio of U.S. labour output/productivity per labour dollar,

- the growing concern toward environmental issues,

- real and anticipated volatility in currency valuation,

- increasing theft of intellectual property when dealing with global regions,

- the fast response time and leaner supply chain associated with locating manufacturing closer to the end customer/consumer,

- perception of quicker recovery in the case of supply chain disruption (Ellram et al. 2013, pp. 14-15).

According to J.V. Gray et al., the combination of the following changes must have taken place to lead to the reversion from offshoring to reshoring:

- changes in the exogenous cost drivers in locations, such as wage rates and currency,

- changes in the managerial valuation of the true total cost of offshoring relative to producing locally.

Recent data cited by S. Kinkel (2014, p. 64) reflect that approximately $20 \%$ of German companies' reshoring decisions might be characterized as mid-term or long-term reactions to a changing local environment and location advantages, but $80 \%$ can be characterized as a short- to mid-term correction mechanism. Results of international surveys highlighted that the original offshoring decisions were based in particular on the unit purchase prices, with little consideration for total costs. The cost estimation errors have negative consequences for the process performance of the activity relocated abroad (Larsen 2015, pp. 1-2). Among others, total supply chain costs and external risks were discounted as hidden. As a result of this finding, some companies have developed offshoring practices based on the easily measureable costs (especially purchase prices) and have reshored after discovering and experiencing total costs and different risks. These barriers should be considered in the Total Cost of Acquisition. 


\subsection{Methodology}

The analysis is based on results of the author's own questionnaire survey conducted among purchasing managers representing 60 large companies (with more than 249 employees) from 5 industry sectors: apparel, automotive, chemical, electronic and furniture, located in Poland. The evaluation of effectiveness of global sourcing strategies included countries in the following low-cost regions: Eastern and Central Europe, East and South Asia, Middle and South America and Africa.

Table 1 presents three main groups of barriers to development of global sourcing: static, dynamic and hidden. The framework was adapted from the conceptual note and presentation of E. Hong and M. Holweg, 2009. Respondents evaluated 25 cost barriers to sourcing from each low-cost region on the Likert scale from 1 to 5 . Next, the percentage of particular barriers in the Total Cost of Acquisition was calculated.

Table 1. Cost barriers to global sourcing development

\begin{tabular}{|c|c|c|}
\hline Static barriers & Dynamic barriers & Hidden barriers \\
\hline $\begin{array}{l}\text { Purchase price } \\
\text { ex-factory gate } \\
\text { Customs and duty } \\
\text { to clear products } \\
\text { for } \\
\text { export } \\
\text { Transportation } \\
\text { costs }\end{array}$ & $\begin{array}{l}\text { Costs of increased safety stock } \\
\text { levels } \\
\text { Warehousing costs } \\
\text { Order fulfilment costs } \\
\text { Costs of lost sales and stock-outs } \\
\text { due to unresponsive supply chain } \\
\text { Lower demand forecasts accuracy } \\
\text { due to longer order cycle } \\
\text { Problems with product quality } \\
\text { Lower customer service due to } \\
\text { longer logistics lead times } \\
\text { Long lead times } \\
\text { Limited reliability of deliveries } \\
\text { Reduced flexibility }\end{array}$ & $\begin{array}{l}\text { Time of market research and } \\
\text { choosing new supplier } \\
\text { Difficult and time-consuming negotiations } \\
\text { Management costs, including overheads } \\
\text { and personnel costs } \\
\text { Currency fluctuations } \\
\text { Necessity of know-how transfer } \\
\text { Loss of intellectual property } \\
\text { Legal barrier } \\
\text { Cultural barrier } \\
\text { Language barrier } \\
\text { Corruption and criminality } \\
\text { Political instability } \\
\text { Probability of prices increase }\end{array}$ \\
\hline
\end{tabular}

Source: Ocicka 2012, pp. 170-171

\subsection{TCA analysis}

The complex analysis of the cost barriers enables to choose the best cost sourcing country based on the TCA. The importance of each group varies depending on 
the industry sector and the geographical location of the buying company as well as the supplier. Generally, in perspective of the survey's results, the hidden and dynamic barriers have the greatest influence on global sourcing costs. The percentage of the dynamic costs in the TCA accounts $47.39 \%$ across different industries. The most important dynamic barriers are higher costs of increased stocks $(11.26 \%)$, problems with product quality (5.03\%) and limited reliability, especially poor punctuality of deliveries (5.01\%) in supply chains. Secondly, it is worth indicating that the percentage of the hidden barriers is $40.97 \%$ of the TCA. Last but not least, the author would like to draw the attention to the static barriers. Their percentage amounts to $11.64 \%$ of the TCA from low-cost countries.

The reduction of dynamic and the avoidance of hidden cost barriers in long supply chains are key arguments for reshoring. In contrast, barriers to global sourcing development have become drivers of reshoring. Based on the analysis of the Total Cost of Acquisition or the total landed costs for manufacturing or sourcing of many products on the global stage, the high-wage countries appear increasingly attractive nowadays. The Reshoring Initiative established in the U.S. makes available the estimator software, which shows that when managers consider the total costs of manufacturing in China for U.S. consumption, reshoring becomes attractive strategy (Deligio 2014, p. 26). Reshoring development depends on the industry profile of each company, its strategy and products. The evaluation and trade-off analysis of multiplied factors: costs and risks determine different choices.

Additionally, aspects of social and environmental corporate responsibility should be taken into account (Lee 2010, pp. 66-69). Both aspects might favour reshoring. Besides economic dimension, best practices in supply chain management deliver social and environmental value. Its significance is rising because of legal regulations and stakeholders awareness. The importance of those aspects is reflected in such management practices like e.g. carbon footprint measurement, carbon labelling programs or code of conducts applied in supplier relationships management. Environmental sustainability and social responsibility are pillars of the best value sourcing (Vitasek et al., 2016, pp. 1-25).

\section{Reshoring effects}

The impact of reshoring should be discussed on different levels of the analysis in terms of economic, social and environmental issues, which also differentiate depending on the macro- and microscale (table 2). On the one hand, some companies proclaim the beginnings of local or regional manufacturing and 
sourcing, enhancing national economies and labour markets. On the other hand, companies focus attention on supply chain capabilities and value creation for customers and other stakeholders.

Table 2. Benefits of reshoring

\begin{tabular}{l|l}
\hline Author & Benefits \\
\hline Nash-Hoff (2011) & $\begin{array}{l}\text { Supporting state economies and exports } \\
\text { Technology and innovation development } \\
\text { Higher number of jobs } \\
\text { Better supplies for national defence } \\
\text { Reduced order cycles and delivery time } \\
\text { Shih (2014) }\end{array}$ \\
$\begin{array}{l}\text { Minimised inventory of goods } \\
\text { Close links between R\&D and production } \\
\text { Quicker respond to market changes }\end{array}$ \\
$\qquad \begin{array}{l}\text { Delivery time improvement } \\
\text { Total Cost of Ownership improvement } \\
\text { Quality improvement and higher productivity } \\
\text { Freight cost and inventory improvement } \\
\text { Wage cost improvement } \\
\text { Customer responsiveness improvement } \\
\text { Influence on image, brand } \\
\text { Innovation/product differentiation improvement }\end{array}$ \\
$\qquad \begin{array}{l}\text { Reduction in delivery and distribution costs } \\
\text { Faster reaction to demand fluctuations } \\
\text { More robust protection of intellectual property }\end{array}$ \\
\hline
\end{tabular}

Source: own study based on literature review

Reshoring causes direct shift of sourcing and manufacturing strategies in supply chains. The trend to moving only production back generates a problem of a hollowed-out supply base in some industries and creates the challenge for supply chains managers to rebuild supplier relations (Shih 2014, pp. 6-7). Furthermore, it should be stated that manufacturing always creates secondary jobs, e.g. every 100 steel or automotive jobs create between 400 and 500 new jobs in the rest of the economy (Nash-Hoff 2011, pp. 41-42). Additionally, development of production operations is the engine of innovations in different fields: technologies, products and processes. As a result, reshoring has rising influence on supply chains configuration, its dynamic depends highly on the industry profile, business strategy of the company and its capabilities. There are some 
bottlenecks that limit the positive effects and success of the reshoring strategy. One of the most important challenges is to stabilize the local workforce in some high-wage countries. Results of the research on shifts in global production systems conducted at the Harvard Business School, identified components enhancing this barrier like: worker understanding and expectations regarding production job in a modern factory, management's ability to give workers reasons to stay, generational skills deficiency in many important technical areas in developed countries (Shih 2014, pp. 2-4). There is the greatest challenge of shortage of skilled co-workers qualified in engineering and technical areas, due to the real offshoring exodus in those regions from the 1990s. Now it's time for recovery and development of new talents well prepared and motivated to work in modern, high-technology driven leading factories managed in best possible, efficient and effective way.

Is there any serious reshoring boom that should be noticed? There are many successful examples of reshoring companies in various countries, e.g. in the U.S. The flagship firm - General Electric decided to reshore appliances production to Louisville in the U.S. This case study highlights the new perspective for demand driven supply chain management, enhanced by pull strategy and lean planning system. As a result, products are more affordable, the unit retail price might be reduced from 1600 USD (made in Asia) to 1200 USD made domestically (Render, 2012). Besides such successful business strategies, the evaluation of the reshoring role in global supply chains management should have a broader perspective.

A.T. Kearney calculates the U.S. Reshoring Index, which positive value indicates net reshoring and a negative number indicates net offshoring. In 2015 the index dropped to -115 , from -30 in 2014. This change highlights the largest year-over-year decrease in the past 10 years. It is worth explaining that the U.S. Reshoring Index takes into account the import of manufactured goods from the following Asian offshore trading partners: China, Taiwan, Malaysia, India, Vietnam, Thailand, Indonesia, Singapore, Philippines, Bangladesh, Pakistan, Hong Kong, Sri Lanka and Cambodia, as well as the U.S. domestic gross output of manufactured goods. On the basis of these values, the manufacturing import ratio is calculated as a percentage of the import according to domestic value of goods. The ratios during last years were as follows: $2004-7.7 \%, 2005-8.2 \%$, $2006-9.0 \%, 2007-9.1 \%, 2008-9.2 \%, 2009-9.6 \%, 2010-10.5 \%, 2011-10.4 \%, 2012$ - 10.6\%, $2014-10.9 \%, 2015$ with regards to forecasts - 12.0\% (A.T. Kearney, 2015).

Moreover, Deloitte surveyed 140 companies worldwide to recognise key emerging trends. One of the main trends is location strategy, but only $16 \%$ of respondents have moved work or are planning to move work back to their home 
country. This global minority outlined offshore supplier performance $-72 \%$, inability to realize cost advantage $-44 \%$ and customer perceptions $-28 \%$ as the most important drivers of such decisions (Deloitte 2013, p. 5). Despite predictions of some experts, offshoring continues the trend upward. Labour costs in China are rising, but there are still other attractive foreign locations with cheap labour resources. Companies discover and exploit new "low-cost" sourcing and manufacturing destinations successfully. Especially, they are interested in countries that emerge as future demand centres of great magnitude to be in close proximity to customers.

In light of the studies carried out globally, reshoring is one of the global supply chains strategies and a lot of companies achieve advantages relocating recently sourcing or production back to their home countries and/or regions. According to Bals et al., the following factors will significantly influence reshoring trend in the near future: importance of controlling supply chains, standardization of regulations (including environmental and social standards), political incentives and new technologies (Bals et al. 2015, pp. 5-6).

\section{Conclusion}

It is a fact that companies restructure supply chains, searching continuously for the best sourcing and manufacturing locations. The analysis allows to notify that changes in supply chains configurations have no one direction and companies made different decisions taking into account various reasons and factors. In recent years, the global shift led to active discussions and predictions of a return of sourcing and manufacturing activities to the countries or regions of companies' origin. The reshoring strategy has emerged as an attractive opportunity, especially for companies that didn't did not achieve expected competitive advantage from offshoring. Nowadays, they might calculate the Total Cost of Acquisition and make the decision to source or manufacture offshore or onshore with regards to the total supply chain costs. Based on the analysis of reshoring drivers and benefits, it is clear that this strategy might have positive influence on the value creation in international and global supply chains management. This paper throws light on three dimensions of the value: economic, social and environmental from perspective of stakeholders. It would be very interesting to develop research study relating to value creation through reshoring across different industry sectors.

Future research studies that might be addressed cover also other areas. One of the most important fields is supply chain design and redesign in light of reshoring 
development. The importance of this research problem is rising, because the dynamic capability to configure and reconfigure supply chains has emerged as a new source of competitive advantage on the global stage in turbulent business environment of the $21^{\text {st }}$ century. From the perspective of countries in Central and Eastern Europe, it would be extremely interesting to benchmark companies' reshoring decisions in comparison to firms in most developed countries and regions. Next research question that should be addressed is: what will be the future role of Central and Eastern Europe in geographical configurations of global supply chains?

The understanding of the reshoring strategy in supply chain management requires an empirical ana-lysis on international scale. Most of the publications are focused on reshoring to the home countries. There is lack of studies on the role of near-reshoring strategy that extend significantly perspective of future research.

\section{Summary}

Reshoring: implementation issues and research opportunities At the beginning of the $21^{\text {st }}$ century, we continuously observe shifts in supply chains configurations caused by differentiate trends in turbulent environment. The remarkable number of companies restructure supply chains in search for competitiveness and innovation on global market. On the one hand, some labourintensive industries are moving out of China to the next low-cost countries, on the other hand, some high-tech and innovative manufacturing companies are returning to the developed countries. The scientific purpose of the article is to set out the potential impact of reshoring on value creation in supply chains and to outline research opportunities in this field. Literature review and results of the questionnaire-survey on the Total Cost of Acquisition analysis are guidelines for considerations. Based on the analysis of reshoring drivers and benefits, it is clear that this strategy might have positive influence on the value creation in international and global supply chains management considering three dimensions of the value: economic, social and environmental from perspective of different stakeholders.

Keywords: reshoring, manufacturing and sourcing internationalization, supply chain management, value management 


\section{Streszczenie}

\section{Reshoring: aspekty zastosowań i możliwości badawcze}

Na początku XXI w. obserwujemy ciągłe zmiany w konfiguracji łańcuchów dostaw spowodowaneróżnymi trendami w turbulentnym otoczeniu. Znacząca liczba przedsiębiorstw restrukturyzuje łańcuchy dostaw w dążeniu do konkurencyjności i innowacyjności na globalnym rynku. $Z$ jednej strony, niektóre pracochłonne branże przenoszą się z Chin do innych krajów niskokosztowych, $\mathrm{z}$ drugiej strony, zaawansowane technologicznie i innowacyjne przedsiębiorstwa produkcyjne powracają z produkcją do krajów rozwiniętych. Celem artykułu jest określenie potencjalnego wpływu reshoringu na wartość dostarczaną $\mathrm{w}$ międzynarodowych i globalnych łańcuchach dostaw oraz wskazanie kierunków badań w tym zakresie. Bazując na analizie przyczyn i efektów reshoringu, można stwierdzić, że niniejsza strategia może mieć pozytywny wpływ na tworzenie wartości w zarządzaniu międzynarodowymi i globalnymi łańcuchami dostaw, w odniesieniu do trzech wymiarów wartości: ekonomicznego, społecznego i środowiskowego, z perspektywy różnych interesariuszy.

\section{Słowa}

kluczowe: reshoring, internacjonalizacja produkcji i zakupów, zarządzanie łańcuchem dostaw, zarządzanie wartościa

\section{References}

1. Ancarani A., Di Mauro C., Fratocchi, L. \& Orzes, G. (2015), Prior to reshoring: A duration analysis of foreign manufacturing, "International Journal of Production Economics", 169, 141-155.

2. Arlbjørn J.S., Mikkelsen O.S. (2014), Backshoring manufacturing: Notes on an important but under-researched theme, "Journal of Purchasing \& Supply Management", 20, 60-62.

3. A.T. Kearney (2015), U.S. Reshoring: Over Before It Began? Website: https:// www.atkearney.com/pl/operations/ideas-insights/manufacturing-reshoring (12.03.2016 - access date).

4. Bals L., Daum, A., Tate, W. (2015), From Offshoring to Rightshoring: Focus on the Backshoring Phenomenon, "AIB Insights", 15(4), 3-6.

5. Blecker T., Gemuenden, H.G. (2006), Wertschoepfungsnetzwerke, Erich Schmidt Verlag, Berlin.

6. Carter C.R., Rogers, D.S. (2008), A framework of sustainable supply chain management: moving toward new theory, "International Journal of Physical Distribution \& Logistics Management", 38(5), 360-387. 
7. Cranfield University (2015). An analysis of the UK's Capability to Reshore Production. National Manufacturing Debate, $20^{\text {th }}$ May. Website: https://www. cranfield. ac.uk/ /media/Files/Files-web-migration/UKManufacturing ReshoringWhitepaper2015.ash x?la=en (05.03.2016 - access date).

8. Cushman \& Wakefield (2015), Where in the World? Manufacturing Index 2015. Website: http://www.cushmanwakefield.com/ /media/globalreports/Where\%20In\%20The\%20World_Manufa cturing\%20Index_2015. pdf (01.03.2016 - access date).

9. Deligio T. (2014), The Truth About Reshoring, „Plastics Technology”, March 2014, 26-29.

10. Deloitte (2014), Deloitte's 2014 Global Outsourcing and Insourcing Survey 2014 and beyond. Website: https://www2.deloitte.com/content/dam/ Deloitte/us/Documents/strategy/us-2014-global-outsourcing -insourcing-survey-report-123114.pdf (06.03.2016 - access date).

11. Elkington J. (1998), Cannibals with Forks: The Triple Bottom Line of the $21^{\text {st }}$ Century Business, New Society Publishers, Stoney Creek.

12. Ellram L.M., Tate W.L., Petersen K.J. (2013), Offshoring and reshoring: an update on the manufacturing location decision, "Journal of Supply Chain Management", April, 14-20.

13. Fratocchi L., Di Mauro C., Barbieri P., Nassimbeni, G., Zanoni, A. (2014), When manufacturing moves back: Concepts and questions, "Journal of Purchasing \& Supply Management", 20, 54-59.

14. Gray J.V., Skowronski K., Esenduran G., Rungtusanatham, M.J. (2013), The reshoring phenomenon: what supply chain academics ought to know and should do, ,Journal of Supply Chain Management", April, 27-31.

15. Hong E., Holweg M. (2009), Evaluating the Effectiveness and Efficiency of Global Sourcing Strategies: A Conceptual Note. Website: http://www.innovation.jbs.cam.ac.uk/publications/downloads/hong _evaluating.pdf (10.03.2016 - access date).

16. International Economic Development Council (2015), Defining the reshoring discussion. Reshoring American Jobs. Website: http://www.iedconline. org/clientuploads/Downloads/Reshoring/Reshoring_American _ Jobs. pdf (10.03.2016 - access date).

17. Kamauff J., Spekman, R. (2008), The LCCS success factors, „Supply Chain Management Review", January-February, 14-21.

18. Kearney A.T. (2015), U.S. Reshoring: Over Before It Began? Website: https:/ / www.atkearney.com/pl/operations/ideas-insights/manufacturing-reshoring (12.03.2016 - access date).

19. Kinkel S. (2014), Future and impact of backshoring - some conclusions from 15 years of research on German practices, "Journal of Purchasing \& Supply Management", 20, 63-65.

20. Lambert D.G. (2001), The supply chain management and logistics controversy, in: A.M. Brewer, K.J. Button, D.A. Hensher (Eds.), Handbook of logistics and supply chain management, Elsevier, Oxford. 
21. Lee H. (2010), Don't Tweak Your Supply Chain - Rethink It End to End, "Harvard Business Review”, October, 63-69.

22. Larsen M.M. (2015), Failing to estimate the costs of offshoring: A study on process performance, "International Business Review”, 1-12.

23. Monczka R.M., Handfield R.B., Giunipero L.C., Patterson J.L., Waters D. (2010), Purchasing and Supply Chain Management, South-Western Cengage Learning, Andover.

24. Mueller J., Dagmar A., Hautz, J., Hutter K., Matzler K., Raich M. (2011), Differences in corporate environmentalism - A comparative analysis of leading U.S. and German companies, „European Journal of International Management", 5, 122-148.

25. Nash-Hoff M. (2011), Re-shoring initiative - part II. Websiet: www.metalfinishing.com (25.01.2016 - access date).

26. Ocicka B. (2012), Zmiany w łańcuchach dostaw w świetle rozwoju zaopatrzenia z rynków niskokosztowych, OW SGH, Warszawa.

27. Render B. (2012), OM in the News: Why GE Decided to Reshore Appliance Production. Website: https://heizerrenderom.wordpress. com/2012/03/16/om-in-the-news-why-ge-decided-to-reshore-appliance-produc tion/ (25.01.2016 - access date).

28. Reshoring Initiative. Bringing Manufacturing Back Home. Strona internetowa: http://www.reshorenow.org/ (26.01.2016 - access date).

29. Rutkowski K. (red.) (2009), Best Practices in Logistics and Supply Chain Management. The Case of Poland, OW SGH, Warszawa.

30. Shih W.C. (2014), What It Takes to Reshore Manufacturing Successfully, „MIT Sloan Management Review", August 7, 1-8.

31. Stevens J. (2016), The benefits of reshoring manufacturing: an overview. Website: http://www.reshorenow.org/blog/the-benefits-of-reshoringmanufacturing-an-overview / (16.02.2016 - access date).

32. Van den Bossche P., Gupta P., Gutierez H., Gupta, A. (2014), Solving the Reshoring Dilemma, "Supply Chain Management Review", JanuaryFebruary, 26-33.

33. Vitasek K., Snelgrove T., Evans D., Tate W., Keith B., Holliman, S., Unpacking Best Value. Understanding and Embracing Value Based Approaches for Procurement. Website: http://www.vestedway.com/wp-content/ uploads/2012/11/TCO-Best-Value-White-Paper.pdf (15.02.2016- access date).

34. Young R.R., Swan P.F., Thomchick E.A., Ruamsook, K. (2009), Extending landed cost models to improve offshore sourcing decisions, "International Journal of Physical Distribution \& Logistics Management", 39 (4), 320-335. 